\title{
Ichthyological

\section{Standardisation of recipe for batter and breaded product Acetes cutlet from Jawala, Acetes indicus}

\author{
Kudale, A. S. ${ }^{1}$, Pagarkar, A. U. ${ }^{2}$, Gaikwad, B. V. ${ }^{3}$, Ranveer, R. C. ${ }^{1}$ Pujari, K. H. ${ }^{1}$, Rathod N. B. ${ }^{1}$,
} H. Singh ${ }^{2}$, Shargandhar, S.T. ${ }^{3}$, Swami, S. B. ${ }^{1}$, Shingare, P. E. ${ }^{4}$ Phadtare M. C. ${ }^{1}$ and

Sawant, N. H. ${ }^{2}$

${ }^{1}$ Post Graduate Institute of Post Harvest Management, Killa-Roha, Dist: Raigad, Maharashtra (India)

${ }^{2}$ Marine Biological Research Station, (Dr. B. S. Konkan Krishi Vidyapeeth, Dapoli) Ratnagiri - 415612 ,

Maharashtra (India)

${ }^{3}$ College of Fisheries, Shirgaon, (Dr. B. S. Konkan Krishi Vidyapeeth, Dapoli) Ratnagiri - 415629 ,

Maharashtra (India)

${ }^{4}$ Taraporewala Marine Biological Research Station, (Dr. B. S. Konkan Krishi Vidyapeeth, Dapoli) Mumbai 400052, Maharashtra (India)

\section{ABSTRACT}

Acetes is a small sized shrimp, locally known as 'Jawala' or 'Kolim' is landed along the north-west coast in the states of Gujarat and Maharashtra, India. At present the fresh utilization of Acetes is very limited. One of the most important food product is battered and bearded product. A standardized recipe of batter and breaded Acetes product is mentioned in the paper. Acetes cutlet having a standard size of 2.0-3.5 cm in length $\mathrm{cm}$ diameter, $1 \mathrm{~cm}$ thickness and $0.2-0.5 \mathrm{~g}$ weight Acetes cutlets were standardized by using different ingredients viz., cooked potatoes, salt, green chilly (C) and ginger $(G)$. Prepared of cutlets were standardized by organoleptic evaluation. It was found that, Acetes cutlet prepared with the ratio of 75:100 (w/w), 20:100 (w/w), 5.5:100 (w/w), 5.5:100 (w/w) and 2.5:100 (w/w) for potato: Acetes mince, onion: Acetes mince, green chilly: Acetes mince, ginger: Acetes mince and table salt: Acetes mince respectively, ratios showed highest score as compared to other ratios tried in the experiments.

KEY WORDS: ACETES, BATTER AND BREADED PRODUCT, INGREDIENTS, SENSORY EVALUATION, VALUE ADDED PRODUCTS

\section{ARTICLE INFORMATION:}

Corresponding Authors: pagarkarau@gmail.com, ajaykudale21@gmail.com

Received $17^{\text {th }}$ Sep, 2018

Accepted after revision $12^{\text {th }}$ Dec, 2018

BBRC Print ISSN: 0974-6455

Online ISSN: 2321-4007 CODEN: USA BBRCBA

Thomson Reuters ISI ESC / Clarivate Analytics USA

:\%ono of Clarivate Analytics and Crossref Indexed Journal Mono of $C R$

NAAS Journal Score 2018: 4.31 SJIF 2017: 4.196

- A Society of Science and Nature Publication, Bhopal India 2018. All rights reserved.

Online Contents Available at: http//www.bbrc.in/

DOI: $10.21786 / \mathrm{bbrc} / 11.4 / 5$ 


\section{INTRODUCTION}

Acetes is widely distributed in different parts of the world with dominance along the coast of many countries bordering the Indian Ocean. Acetes is a small sized shrimp, belongs to family Sergestidae, genus Acetes and scientifically named as Acetes indicus. In India, a substantial quantity of this group locally known as 'Jawala' or 'Kolim' is landed along the north-west coast in the states of Gujarat and Maharashtra (Zynudheen, 2004; Mahakal et al., 2016). At present the fresh utilization of Acetes is very limited and people locally people consume Jawala or Kolim regularly either in fresh or dried form in the preparation of day-to-day food dishes. Acetes is consumed mostly in dried form due to its availabity throught out year in market. But consumption of dry Acetes is more during non-fishing season when fresh fish is not available (Zynudheen et al., 2004; Mahakal et al., 2016; Shaikh et al., 2017).

Now a days consumer's particularly urban area are showing more and more interest in seafood products which are available in ready-to-eat or ready-to-cook in convenience form. Recent scenario peoples both man and women are engaged in jobs and they hardly find time to cook food. This leads to reasonably increase in their income and they become more depend on ready-to-eat, ready-to-cook and ready-to-fry types of products available in market (Balachandran, 2001; Pagarkar et al., 2011). One of the most important foods in ready-to-eat and ready-to-cook group is battered and breaded products. The process of coating with batter and bread crumbs increases the bulk of the product, thereby reducing the content of costly fish (Pagarkar et al., 2012). Keeping this in view, the present research work was undertaken to develop a battered and breaded product from low cost shrimp locally called as Jawala or Kolim (Acetes indicus).

\section{MATERIAL AND METHODS}

Acetes (Acetes indicus) procured from fish market of Alibaug, district Raigad of Maharashtra coast of India, was brought to processing hall under iced condition. Acetes were washed with potable water, cleaned and cooked in boiled water for 15 min., the cooked Acetes mince was prepared using a grinder. Prepared Acetes mince was placed in polythene bags then it was frozen and stored in deep freezer at a $-20^{\circ} \mathrm{C}$ temperature until further use. As and when required, Acetes mince was taken out and thawed before use. Cooked potatoes were peeled and mashed and made into a fine paste. Chopped onions were fried in sunflower oil till they became brown. Bread crumbs were used as a coating material.

Standardization in the basic recipe (Pawar, et al., 2012) as shown in Table 1 was used by varying the ratios of different ingredients. Firstly the Acetes mince was mixed with boiled potatoes, turmeric powder and salt, a mixture of these was kept aside, then chopped onions were fried in oil until brown in colour then mixed with green chilly, ginger and garlic paste followed by the powdered spices (Turmeric powder, pepper powder, cinnamon powder and clove powder) then mixing of mince base with the fried spices and cooked. Then cutlets of $40 \mathrm{~g}$ were taken and flattened to $1 \mathrm{~cm}$ thickness, dipped into batter mix (Pawar, 2011) rolled over bread crumbs and fried in sunflower oil till they became brown in colour then were subjected to sensory evaluation.

Acetes cutlet were prepared keeping the constant level of oil $10 \mathrm{ml}(\mathrm{w} / \mathrm{w})$, powdered spices (Turmeric powder $0.2 \mathrm{~g}$ $(\mathrm{w} / \mathrm{w})$, pepper powder $0.3 \mathrm{~g}(\mathrm{w} / \mathrm{w})$, cinnamon powder $0.2 \mathrm{~g}$ $(\mathrm{w} / \mathrm{w})$, clove powder $0.3 \mathrm{~g}(\mathrm{w} / \mathrm{w})]$ and bread crumbs $20 \mathrm{~g}$ $(\mathrm{w} / \mathrm{w})$ while varying quantities of cooked potatoes, onion, green chilly (C), ginger (G), and table salt, were used for standardising the recipe. The fried cutlet were subjected to organoleptic evaluation by a group of ten trained panellist using 9 point hedonic scale (ISI, 1975) on the attributes such as colour, taste, texture, odour and overall acceptability. Potato was standardised in basic recipe and Acetes cutlet was prepared with incorporation of different ratios of potato to Acetes mince such as 60:100 (T1), 65:100 (T2), 70:100 (T3), 75:100 (T4) and 80:100 (T5) (w/w). All other ingredients were kept constant. Organoleptic evaluations were carried out to find best ratio.

Onion was standardised in basic recipe and Acetes cutlets were prepared keeping the standard ratio of potato obtained from its standardisation 75:100 (T4), with different ratios of onion to Acetes mince, such as 15:100 (T1), 20:100 (T2), 25:100 (T3), 30:100 (T4) (w/w) and 35:100 (T5) $(w / w)$. All other ingredients were kept constant and prepared Acetes cutlets were organolpetically evaluated for the best combination. Raios of green chilly (C) was standardised in basic recipe and Acetes cutlet was prepared keeping standard ratio of potato 75:100 (T4) and onion 20:100 (T2) with different ratios of green chilly (C) to Acetes mince such as 4:100 (T1), 4.5:100 (T2), 5:100 (T3), 5.5:100 (T4) (w/w) and 6.0:100 (T5). All other ingredients were kept constant. Prepared cutlets were organoleptically evaluated for the best combination.

Ratio of ginger (G) was standardised in basic recipe and Acetes cutlets were prepared keeping standard ratio of potato 75:100 (T4), onion 20:100 (T2) and 5.5:100 (T4) with different ratios of ginger (G) to Acetes mince such as 4:100 (T1), 4.5:100 (T2), 5:100 (T3), 5.5:100 (T4) (w/w) and 6.0:100 (T5). All other ingredients were kept constant. Prepared cutlets were organoleptically evaluated for the best combination.Table salt was standardised as basic recipe and Acetes cutlet was prepared keeping the standard ratio of green chilly and ginger obtained from its standardisation 5.5:100 (T4), with different ratios of salt to Acetes 


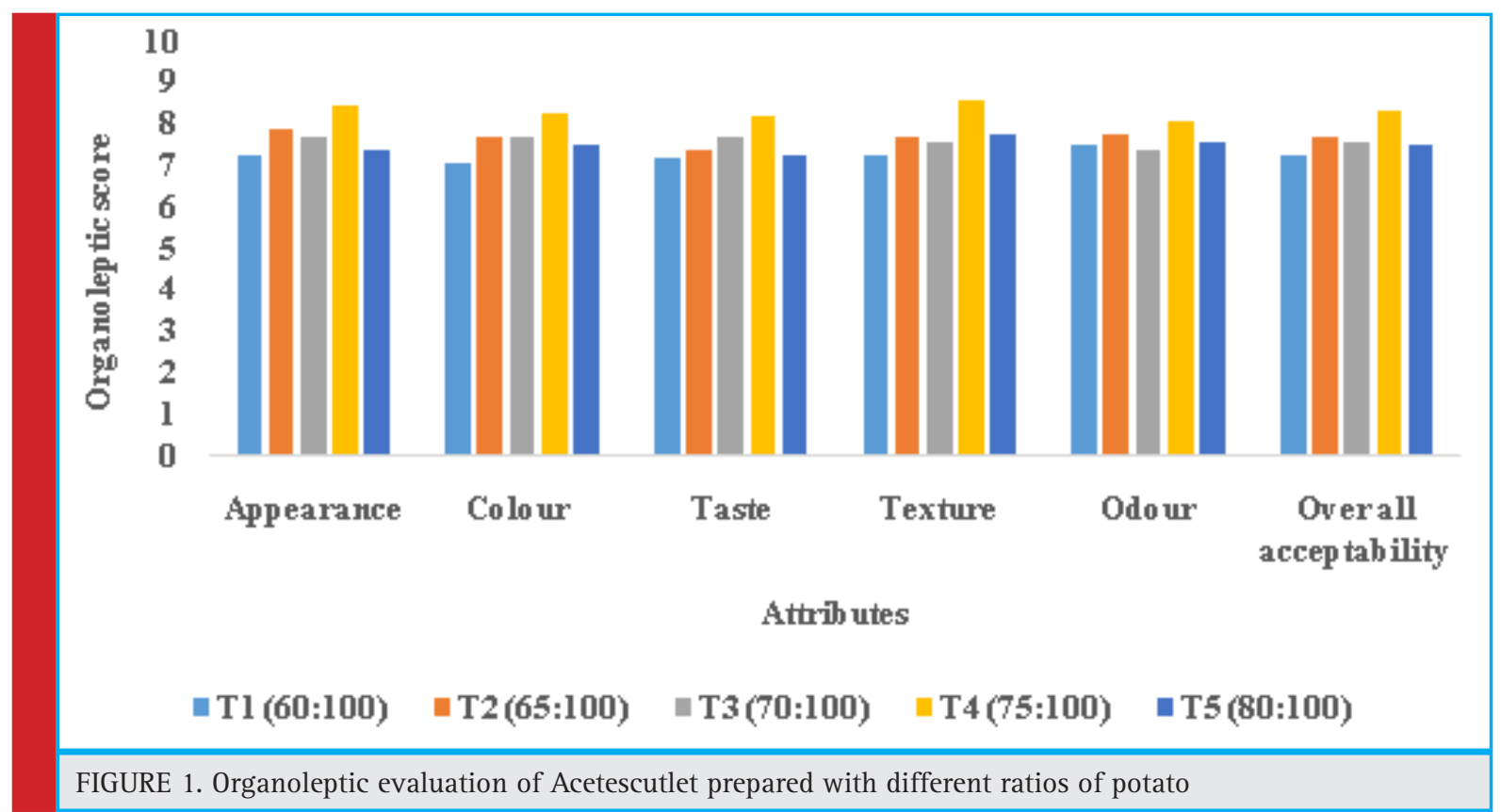

mince, such as 2:100 (T1), 2.5:100 (T2), 3:100 (T3) and 3.5:100 (T4) (w/w) and 4:100 (T5). All other ingredients were kept constant and prepared cutlets were organoleptically evaluated for the best combination.

Finally, Acetes cutlets were prepared using standardised recipe (Table 1) keeping the standardised ratios of potato 75:100 (T4), onion 20:100 (T2), ratios of green chilly 5.5:100 (T4), ginger 5.5:100 (T4) and salt 2.5:100 (T2). Proximate composition viz. moisture, crude protein, crude fat, ash and carbohydrate ( $\mathrm{CHO}$ ) content of Acetes cutlets were determined following standard methods (AOAC, 2005).

\section{RESULTS AND DISCUSSION}

Standardisation of different ingredients viz., potato 75:100 (T4), onion 20:100 (T2), chilly 5.5:100 (T4), ginger 5.5:100 (T4) and table salt 2.5:100 (T2), showed better organoleptic values compared to other ratios (Fig. l, Fig. 2, Fig. 3, Fig. 4 and Fig. 5). The organoleptic evalua-

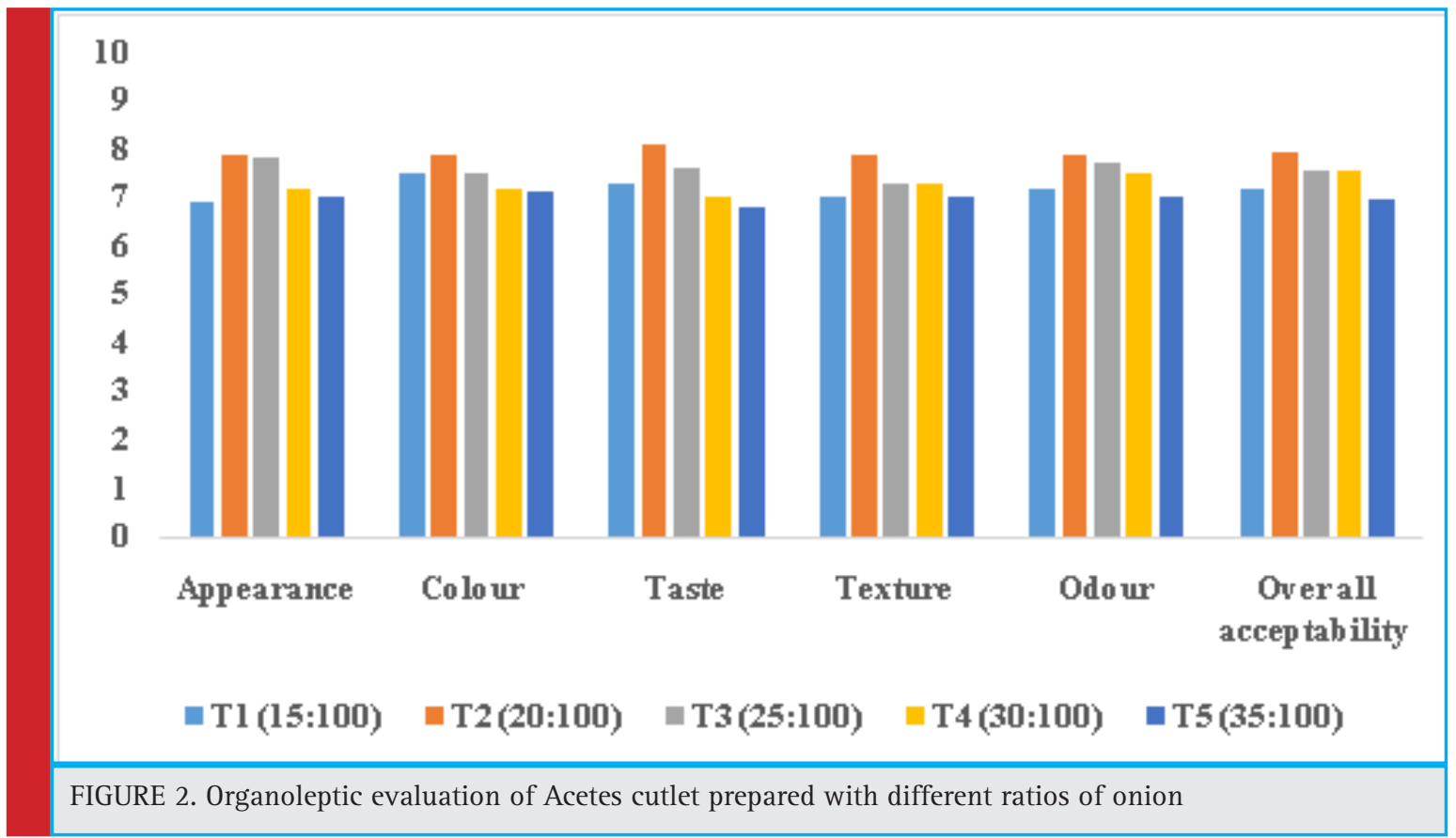




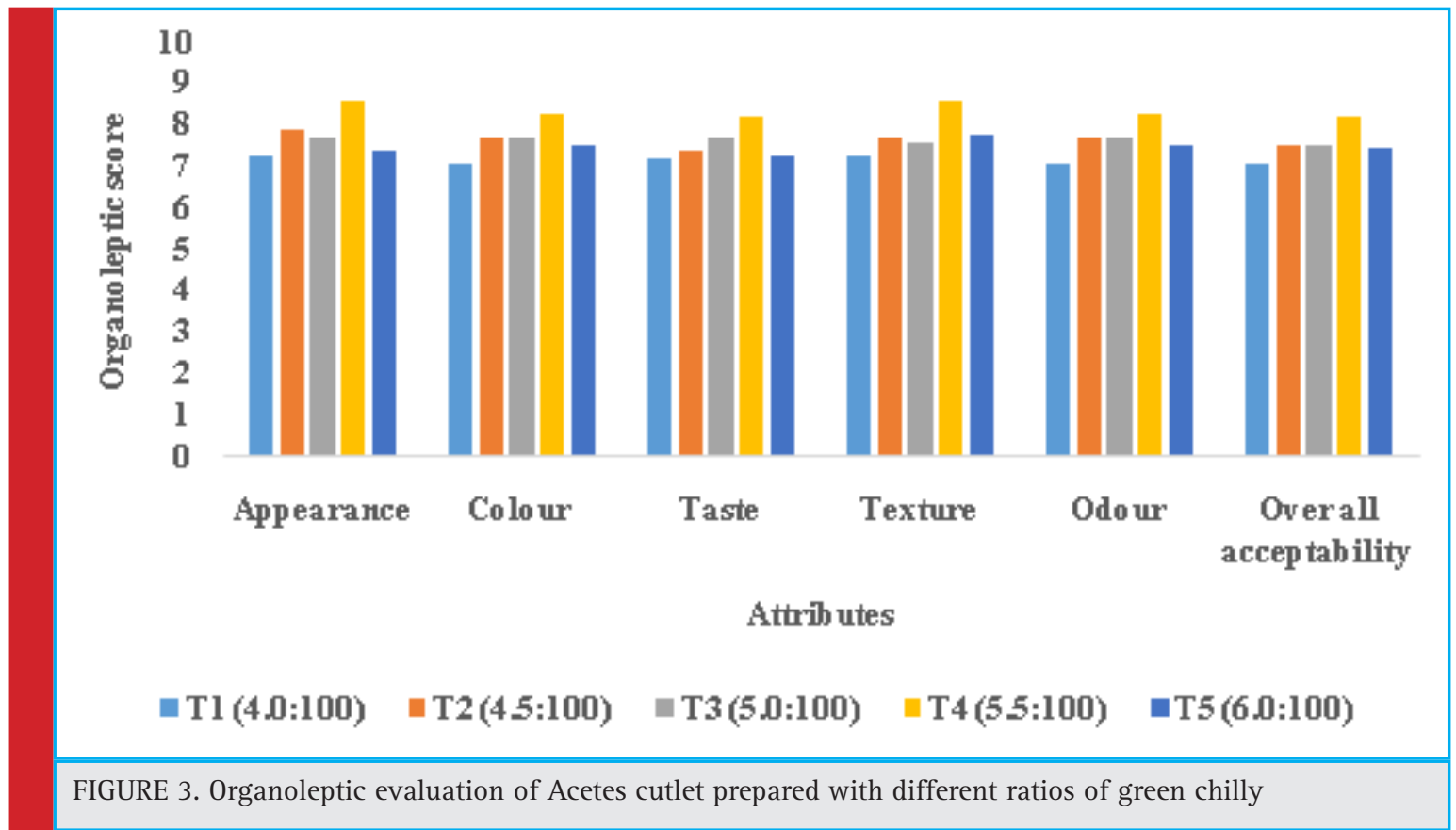

tion of the cutlets indicated the highest score this standardised recipe as shown in Table 2 and Fig.6.

\section{Standardization of different ratios of potato to Acetes} mince in Acetes cutlet

Acetes cutlet prepared with 75:100 (w/w) ratio of potato to Acetes meat was superior as compared to the other ratios of potato to Acetes mince used for preparation of cutlets. Joseph and Perigreen (1989) used 50:100 ratio of potato in the cutlet prepared from horse mackerel, ribbon fish, pola, vatta and mackerel tuna. Kamat (1999) used 50:100 ratio of potato in cutlet prepared from mackerel (Rastrelliger kanagurta). Pawar et al. (2012) used 70:100 ratio of potato in the cutlet prepared from catla. Rathod et al. (2012) used 70:100 ratio of potato in the cutlet prepared from Pangassius (Pangasianodon hypothalamus). Species differentiation and higher ratio of potato to mince increased more starch and taste in the cutlet

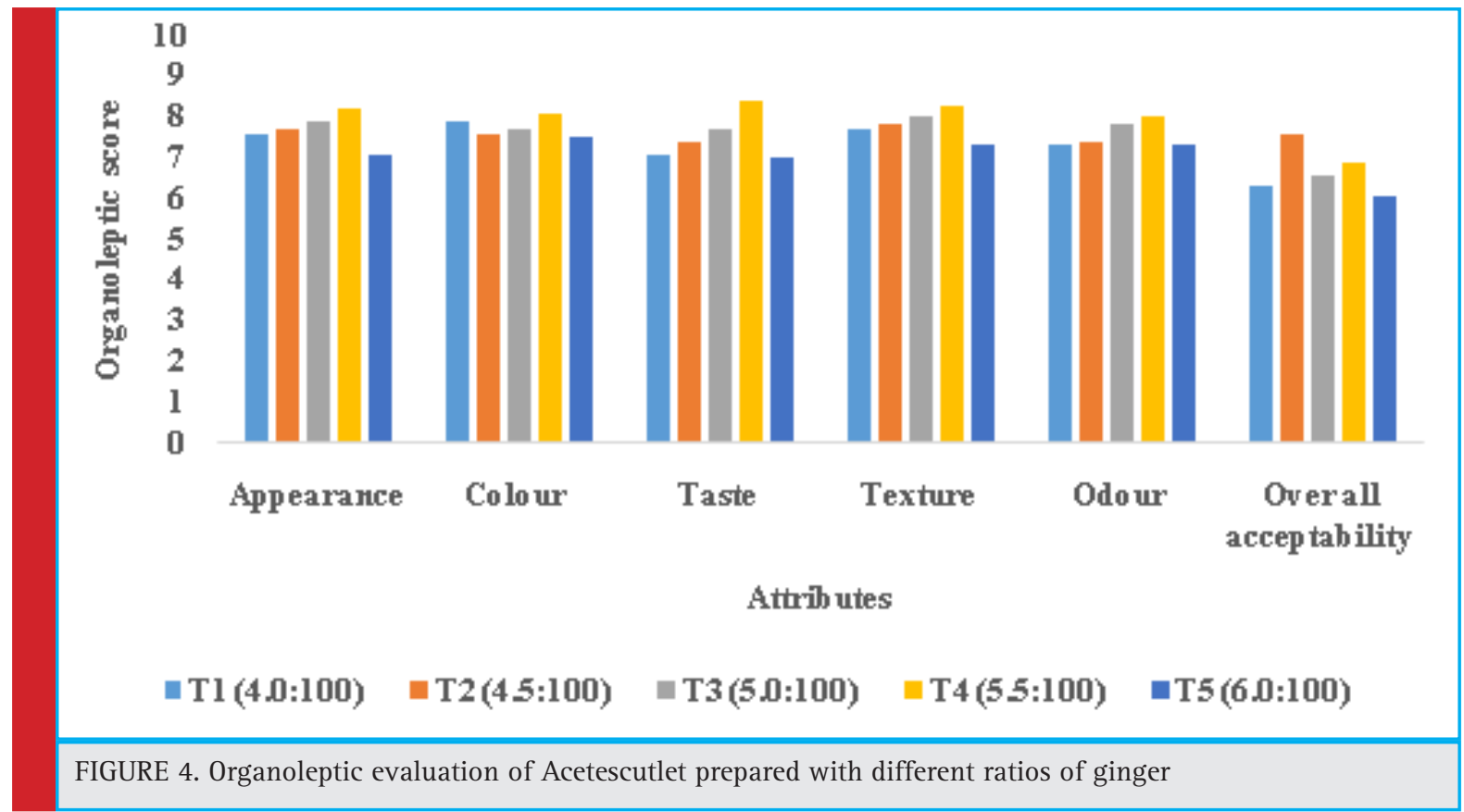




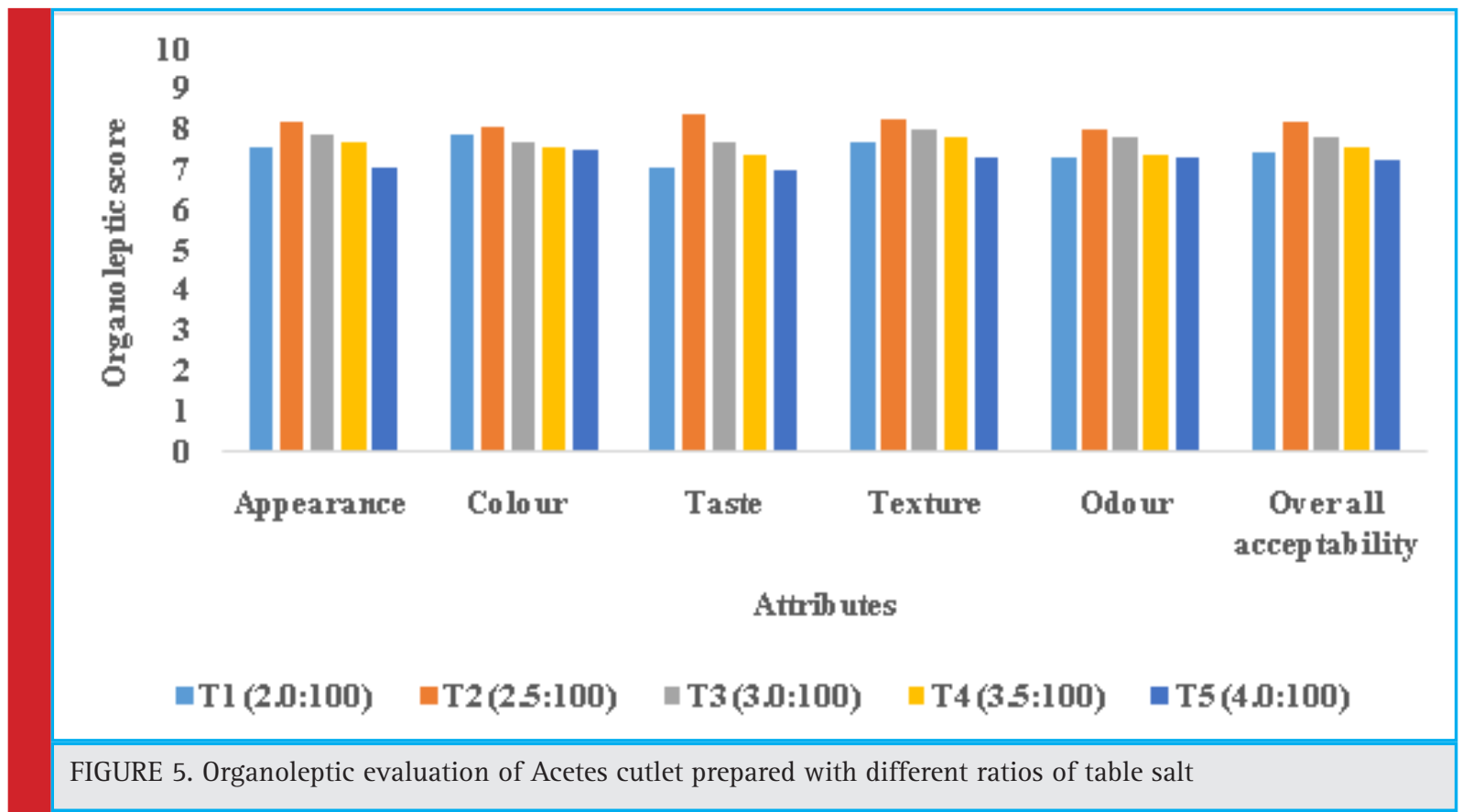

and bind all ingredients properly. Higher potato ratio reduces strong odour of Acetes as well as cost of the cutlets. Similar results with slight variation were found by Joseph, Perigreen (1989), Kamat (1999), Pawar et al. (2012) and Rathod et al. (2012).

\section{Standardization of different ratios of onion to Acetes mince in Acetes cutlet}

Acetes cutlets were prepared with 20:100 (w/w) ratio of onion to Acetes meat was superior as compared to the other ratios of onion to Acetes meat used for preparation of cutlet. Kamat (1999) used 25:100 ratio of onion in cutlet prepared from mackerel ( $R$. kanagurta). Pawar et al. (2012) used 25:100 (w/w) ratio of onion to catla (catla) meat. Rathod et al. (2012) used 25:100 ratio of onion in the cutlet prepared from Pangassius ( $P$. hypothalamus). Species differentiation may cause difference in the ratio of onion to meat. In the present, study as per the opinion of panellist, the higher ratio of onion gave a very excellent taste to the cutlets. Therefore, the

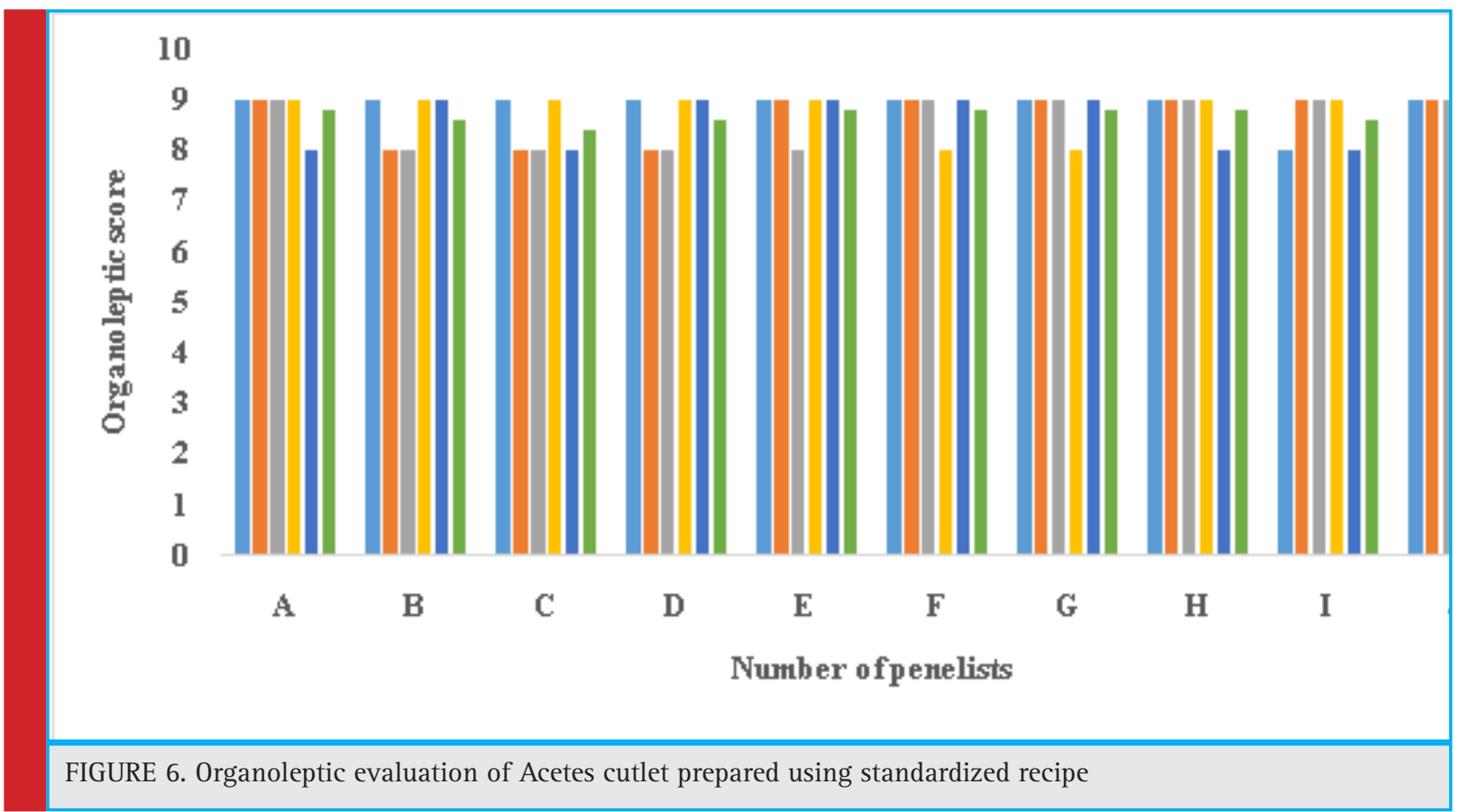




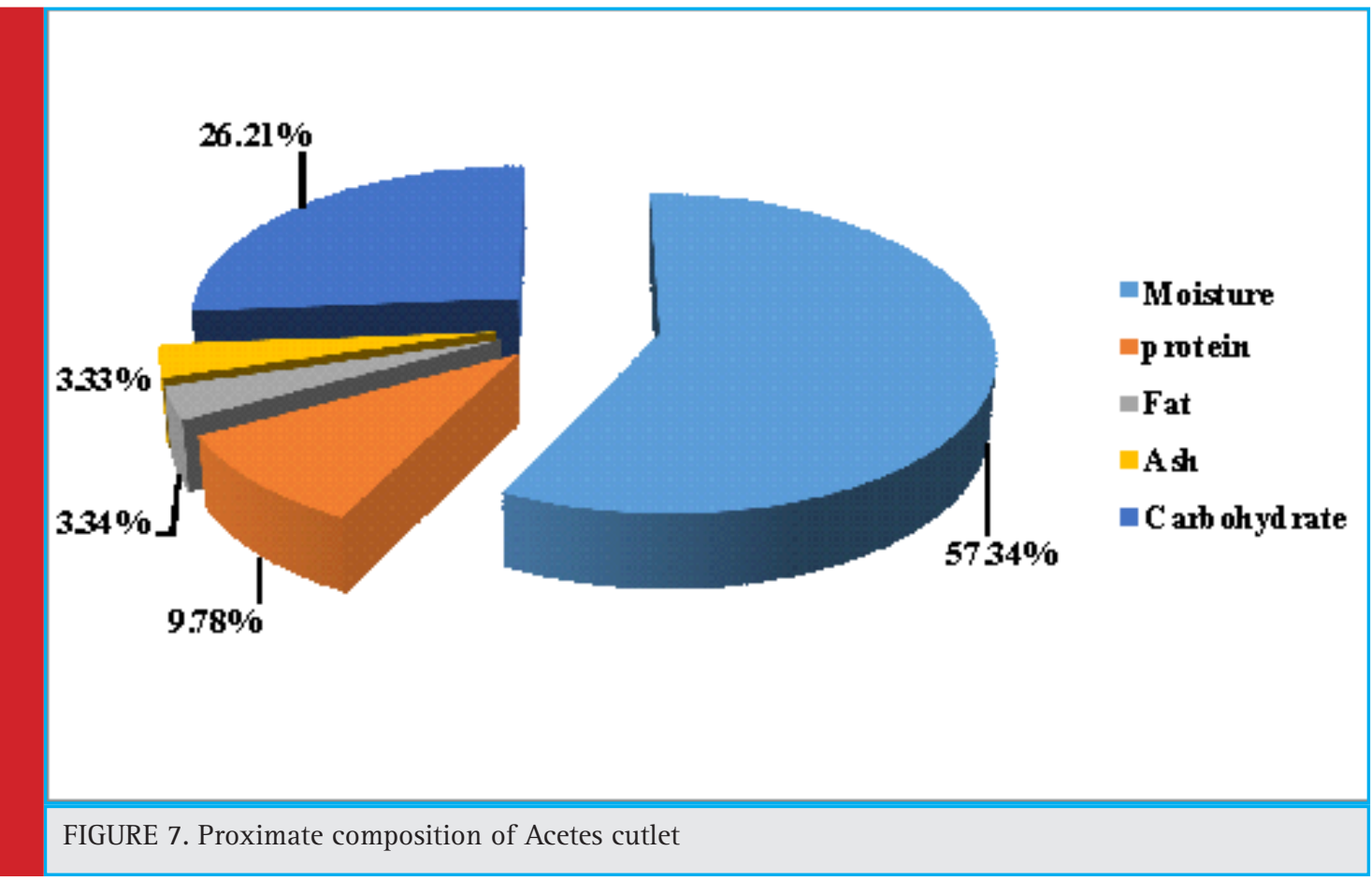

ratio of 20:100 (w/w) onion to meat was used for better taste.

\section{Standardization of different ratios of green chilly to Acetes mince in Acetes cutlet}

Acetes cutlet prepared with 5.5:100 (w/w) ratio of green chilly to Acetes meat was superior as compared to the

Table 1. Basic and standardized recipe of batter and breaded Acetes cutlet

\begin{tabular}{|l|c|c|} 
Ingredients & $\begin{array}{c}\text { Basic recipe } \\
\text { (Pawar } \\
\text { et al., 2012) } \\
\text { Quantity (g) }\end{array}$ & $\begin{array}{c}\text { Standardized } \\
\text { recipe } \\
\text { Quantity (g) }\end{array}$ \\
\hline Acetes mince & 100 & 100 \\
\hline Table salt & 3 & 2.5 \\
\hline Green chilly & 5 & 5.5 \\
\hline Coriander leaves & 5 & 5 \\
\hline Ginger & 5 & 5.5 \\
\hline Garlic & 5 & 5 \\
\hline Onion & 25 & 20 \\
\hline Potato cooked & 70 & 75 \\
\hline Pepper powder & 0.3 & 0.3 \\
\hline Clove powder & 0.3 & 0.3 \\
\hline Cinnamon powder & 0.2 & 0.2 \\
\hline Turmeric powder & 0.2 & 0.2 \\
\hline Bread powder & 20 & 20 \\
\hline Note: 0il was used 10 ml for heating purpose \\
\hline
\end{tabular}

other ratios of green chilly to Acetes mince used for preparation of cutlet. Kamat (1999) used 6.5:100 ratio of green chilly in cutlet prepared from mackerel $(R$. kanagurta). Pawar et al. (2012) used 5:100 ratio of green chilly in cutlet prepared from catla and similar Rathod et al. (2012) used 5:100 ratio of green chilly in cutlet prepared from Pangassius ( $P$. hypothalamus) fish. In the present study as per the opinion of panellist, the higher ratio of green chilly was giving a very spicy taste of cutlet. Therefore, the ratio of 5.5:100 (w/w) green chilly to meat was used for better taste.

\section{Standardization of different ratios of ginger to Acetes} mince in Acetes cutlet

Acetes cutlets were prepared with 5.5:100 (w/w) ratio of ginger to Acetes meat was superior as compared to the other ratios of ginger to Acetes meat was used for prepa-

\begin{tabular}{|c|c|}
\hline Attribute & Organoleptic Score \\
\hline Appearance & $8.90 \pm 0.32$ \\
\hline Colour & $8.70 \pm 0.48$ \\
\hline Taste & $8.60 \pm 0.52$ \\
\hline Texture & $8.70 \pm 0.48$ \\
\hline Odour & $8.60 \pm 0.52$ \\
\hline Overall Acceptability & $8.70 \pm 0.14$ \\
\hline
\end{tabular}


ration of the cutlet. Kamat (1999) used 7.5:100 ratio of ginger in cutlet prepared from mackerel ( $R$. kanagurta). Pawar (2011) used 5:100 (w/w) ratio of ginger to catla (catla) meat. Rathod et al. (2012) used 6:100 ratio of ginger in cutlet prepared from Pangassius ( $P$. hypothala$m u s)$. Species segregation may cause difference in the ratio of ginger to meat. In the present study as per the opinion of panellist, the higher ratio of ginger made the cutlets little spicy. Therefore, the ratio of $6: 100(\mathrm{w} / \mathrm{w})$ ginger to meat were used for better taste.

\section{Standardization of different ratios of table salt to Acetes mince in Acetes cutlet}

Acetes cutlets were prepared with 2.5:100 $(\mathrm{w} / \mathrm{w})$ ratio of table salt to Acetes meat was superior as compared to the other ratios of salt to Acetes meat used for preparation of cutlet.

Similar results were observed by Joseph et al. (1984) they used 3:100 ratio of salt in the cutlet prepared from lizard fish, threadfin bream, jew fish and miscellaneous fish (comprising mainly soles, caranx, jew fish, threadfin bream and glassy perch). Ninan et al. (2008) used 3:100 ratio of salt in cutlet prepared from tilapia (0. mossambicus). Pawar et al. (2012) used 3:100 ratio of salt in the cutlet prepared from catla (Catla catla). Rathod et al. (2012) used 2.5:100 ratio of salt in cutlet prepared from Pangassius ( $P$. hypothalamus). Species differentiation may cause difference in the ratio of salt to meat. In the present study as per the opinion of panellist, the higher ratio of salt was giving a more salty taste to the cutlet. Therefore, the ratio of $2.5: 100(\mathrm{w} / \mathrm{w})$ salt to meat was used for better taste.

The proximate composition of Acetes cutlet showed moisture $57.34 \%$, crude protein $9.78 \%$, fat $3.34 \%$ and ash $3.33 \%$ and carbohydrate 26.21\% (Fig 7). The increase in fat and reduction in moisture content in cutlet is due to deep frying with dehydration during chilled storage (Ninan et al. 2008 and Pawar et al. 2012). The reduction of protein is due to denaturation fish muscle during chilled and frozen storage (Gopakumar, 2002; Pawar et. al., 2013; Rathod et al., 2014). Joseph et al. (1984) reported moisture, protein, fat and ash content in flash fried cutlet was 62.65, 15.41, 5.92 and 1.88\% respectively. Crab cutlet prepared by Raju et al. (1997) content and may found of moisture, protein, fat and ash were $67.72,17.07,8.36$ and $4.00 \%$ respectively. Kamat (1999) reported fish cutlet prepared from bleached and unbleached fish meat content of moisture, protein, fat and ash were 65.01, 12.06, 6.31 and $1.39 \%$. Ninan et al. (2008) reported tilapia fish cutlet content of moisture, protein, carbohydrate, fat and ash were 65.10, 17.51, 13.47, 2.14 \%. Pawar et al. (2012) reported initial moisture, protein, fat and ash content in flash fried cutlets was $65.71,16.57,14.50$ and 3.22\% respectively. Rathod et al. (2014) reported moisture, protein, fat, ash and carbohydrate content in fresh flash fried cutlets was 53.34, 18.43, 21.02, 2.78 and $4.43 \%$ respectively. Praneetha et al. (2017) reported the moisture, protein, fat and ash content in fresh flash fried cutlets was 57.03, 21.74, 7.61, $3.41 \%$ respectively.

\section{CONCLUSION}

Acetes can be utilized by preparing Acetes batter and breaded product like Acetes cutlet using standardized recipe. This standardized recipe showed excellent organoleptic characteristics. This developed technology will be useful to prepare nutritive products from Acetes as well as helpful to increase the income of fisherman, as well as SHG'S etc.

\section{ACKNOWLEDGEMENT}

The authors are thankful to Hon'ble, Vice-Chancellor, other university authorities of Dr. B. S. Kokan Krishi Vidyapeeth, Dapoli, Maharashtra, Post-Graduate Institute of Post-Harvest Management Killa-Roha, Dist. Raigad, Marine Biological Research Station, Ratnagiri and College of Fisheries, Ratnagiri, and all the staff members of both faculties for encouragement and providing necessary facilities and help for the work.

\section{REFERENCES}

AOAC (2005) Official Methods of Analysis, $18^{\text {th }}$ edition. Association of Official Analytical Chemists., Washington DC, USA 246 pp.

Balachandran, K. K. (2001) Battered and breaded products In: Post-harvest technology of fish and fish products. Daya Publishing House, New Delhi, 288-307.

Gopakumar, K. (2002) Biochemical composition of fish In: Textbook of Fish Processing Technology. Directorate of Information and Publishing of Agriculture, ICAR, New Delhi.

ISI, (1975) Guide for sensory evaluation of foods, Part III, Statistical Analysis of Data, Indian Standard Institute, (Part III), IS: 6273.

Joseph, J., Perigreen, P. A. and Thampuran, N. (1984) Preparation and storage of cutlet from low-priced fish. Fishery Technol., 21(1): 70-74.

Kamat, A. H. (1999) Preparation of fish ball and fish cutlet from mackerel mince meat. M.F.Sc. thesis submitted to Dr. Balasaheb Sawant Konkan Krishi Vidyapeeth, Dapoli, Maharashtra, India, $200 \mathrm{pp}$.

Mahakal, B. V., Pagarkar, A. U., Baug, T. E., Chaudhari, K. J. and Kulkarni, G. N. (2016) Organoleptic and biochemical quality characteristics of Acetes chutney packed in polypropylene packs at ambient stored temperature. J. Exp. Zool. India, 19(2): 943-946. 
Mahakal, B. V., Pagarkar, A. U., Baug, T. E., Shinde, K. M., Bhosale, B. P., Bhatkar, V. R., Shingare, P. E., Satam, S. B., Sawant, N. H. and Shaikh, S. M. (2017) Organoleptic, microbiological, biochemical changes of Acetes chutney (ready-to-eat) packed modified atmospheric packaging with nitrogen gas stored at ambient temperature. Biochem. Cell. Arch., 17(2): 645649.

Ninan, G., Bindu, J. and Joseph, J. (2008) Frozen storage studies of mince based products developed from Tilapia, Oreochromis mossambicus (Peters, 1852). Fishery Technol., 45(1): 35-42.

Ninan, G., Bindu, J. and Joseph, J. (2008) Frozen storage studies of mince based products developed from Tilapia, Oreochromis mossambicus (Peters, 1852). Fishery Technol., 45(1): 35-42.

Pagarkar, A. U., Basu, S. and Mitra, A., (2006). Storage characteristics of fish-soya based ready-to-cook extruded product. Asian Jr. of Microbiol. Bioteh. and Envir. Sc.,8 (3): 609614.

Pagarkar, A. U., Baug, T.E., Pawar, P. P. and Kolekar, A. D. (2012) An approach to seafood processing: Battered and breaded products, Journal of FISHCOOPS, 23 (4), 8-14.

Pagarkar, A. U., Joshi, V.R., Baug, T. and Kedar, J. (2011) Value addition is need of Seafood industries, Journal of FISHCOOPS, 23 (4), 8-14.

Pawar P. P. (2011) Preparation of battered and breaded product from freshwater fish (Catla catla). M.F.Sc. thesis submitted to Dr. Balasaheb Sawant Konkon Krishi Vidyapeeth, Dapoli, Maharashtra, India, $93 \mathrm{pp}$.
Pawar, P. P., Pagarkar, A. U., Rathod, N.B., Baug, T.E. and M. A. Rather (2012) Standardisation of Recipe for Fish Cutlet Product from fresh water fish Catla (Catla catla). European J. of Exper. Biology, 2 (6):2043-2048.

Praneetha, S., Dhanpal, K., Reddy, G. V. S., Balsubramainan, A. and Praveen Kumar, G. (2017) Study on the quality of fish cutlet prepared from Rohu (R. rohita) during refrigerated storage., Inter. J. Current Microbio. and Applied Sci. (IJCMAS), 12: 3262-3271.

Raju, C. V., Bhaskar, N. and Dhananjaya, S. (1997) Development of ready-to-fry crab products. Fishery Technol., 34(2): 26-30.

Rathod, N.B., Pagarkar, A.U., Pujari, K. H., Gokhale, N. B. and Joshi, V.R. (2012) Standardisation of recipe for fish cutlet product from Pangasianodon hypophthalmus., Ecol. Env. and Cons., 18 (4): 981-986.

Rathod, N, Pagarkar, A., Phadke, G., Pujari, K. and Chandra, M. (2014) Chemical, microbial and sensory quality changes of fish cutlets, made from Pangasius fish (Pangasianodon hypophthal$m u s)$, during storage in refrigerated display unit $\left(-15\right.$ to $\left.-18^{\circ} \mathrm{C}\right)$, Eco. Env. and Cons. 20 (3): 967-972.

Shaikh S. M., Joshi V. R., Pagarkar A. U., Pai, R. and Balange A. K.(2017) Effect of heat penetration on quality of Acetes ball in curry in retort pouch processed at $121.2^{\circ} \mathrm{C}$ for different durations., J. Exp. Zool. India., 20 (1), 605-610.

Zynudheen, A. A., George, N., Sen, A. and Badonia, R. (2004) Processing and utilization of Acetes indicus (Jawala Prawn). In: Technology Advisory Series No.15, CIFT, Cochin, 6 pp. 